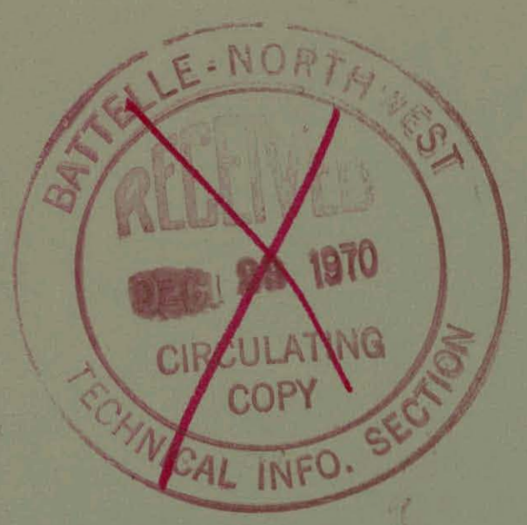

BNWL-B -43
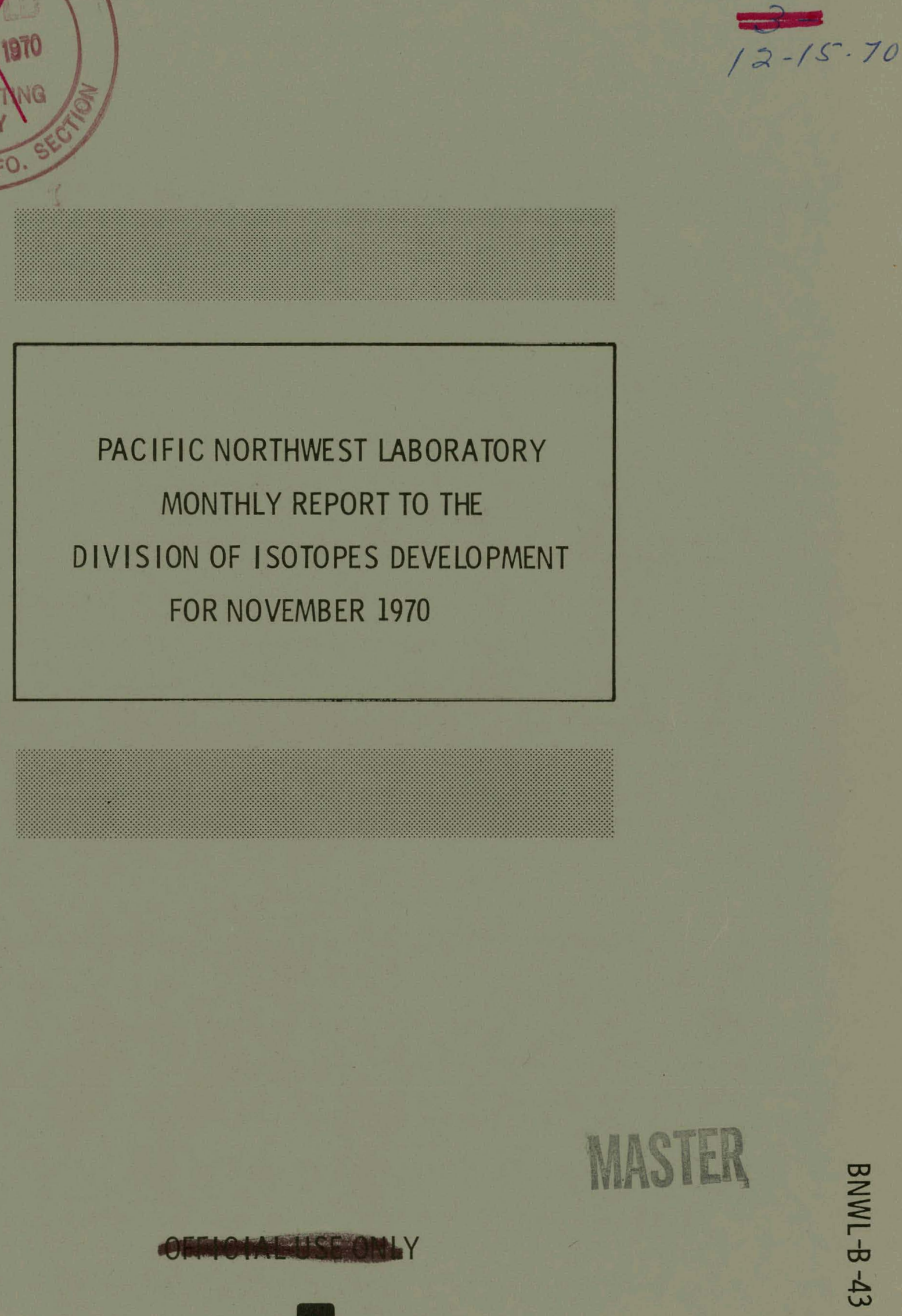

B A T T E L L E 


\section{DISCLAIMER}

This report was prepared as an account of work sponsored by an agency of the United States Government. Neither the United States Government nor any agency Thereof, nor any of their employees, makes any warranty, express or implied, or assumes any legal liability or responsibility for the accuracy, completeness, or usefulness of any information, apparatus, product, or process disclosed, or represents that its use would not infringe privately owned rights. Reference herein to any specific commercial product, process, or service by trade name, trademark, manufacturer, or otherwise does not necessarily constitute or imply its endorsement, recommendation, or favoring by the United States Government or any agency thereof. The views and opinions of authors expressed herein do not necessarily state or reflect those of the United States Government or any agency thereof. 


\section{DISCLAIMER}

Portions of this document may be illegible in electronic image products. Images are produced from the best available original document. 


\section{PATENT STATUS}

This document copy, since it is transmitted in advance of patent clearance, is made available in confidence solely for use in performanee- of work under contracts with the U.S. Atomic Energy Commission. This document is not to be published nor its contents atharwise disseminated or used for purposes other than specified above before patent approval for such release arouse hos been secured. upon hequest, from the Chief, Chicago Patent Group, U. S. Atomic Energy Commissions 9800 So. Cass Ave., Argonne, Illinois.

\section{PRELIMINARY REPORT}

This report contains information of a preliminary nature prepared in the course of work under Atomic Energy Commission Contract AT(45-1)-1830. This information is subject to correction or modification upon the collection and evaluation of additional data.

\section{LEGAL NOTICE}

This report was prepared as an account of work sponsored by the United States Government. Neither the United States nor the United States Atomic Energy Commission, nor any of their employees, nor any of their contractors, subcontractors, or their employees, makes any warranty, express or implied, or assumes any legal liability or responsibility for the accuracy, completeness or useful. ness of any information, apparatus, product or process disclosed, or represents that its use would not infringe privately owned rights.

\section{PACIFIC NORTHWEST LABORATORY}

operated by

\section{BATTELLE MEMORIAL INSTITUTE}

for the

U. S. ATOMIC ENERGY COMMISSION

Under Contract AT(45-1) 1830 


\title{
PACIFIC NORTHWEST LABORATORY \\ MONTHLY REPORT TO THE \\ DIVISION OF ISOTOPES DEVELOPMENT \\ FOR NOVEMBER 1970
}

\author{
Compiled by J. E. Hansen
}

December 15,1970

\section{INFORMATION CONCERNING USE OF THIS REPORT}

\section{PATENT STATUS}

This document copy, since it is transmifted in advance of patent clearance is mademable in confidence laly for use in performance of work sion. This document is not ais a purposes ther than spacifoderbove before patent opprow fosuch release or use has been secured, upon request, from the Chief, Chicago Potent Group, U. S. Atomic Energy Commissionmo800 Sa Cass Ave., Argonne, Illinois.

\section{PRELIMINARY REPORT}

This report contains information of a preliminary nature prepared in the course of work under Atomic Energy Commission Contract AI(45-1)-1830. This informotion is subject to correction or modifica. tion upon the collection and evaluation of additional data.

\section{BEC}

This repart was pepared as an account of Government sponsored work. Neither the United States, nor the Commisstom nor any person acting on behalf of the Commission:

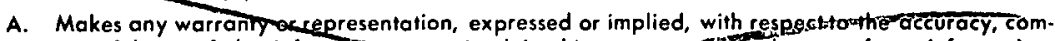
pleteness, or usefulness of the informoliom-antained in this repentsor of that the use of any information, opparatus, method, or process disclosed in this repon and infinge privately owned rights; or

B. Assumes any liabilities withrespect to the use of, or fordamages resulting from the use of any information, apporatusmertiod, or process disclosed in this report. As used.im the above, "person acting on behalf of the Commission" includes any employee or tractor of the Commission, or employee of such contractor prepares, disseminates, or provides access to, any information pursuant to his employment or contract with the Commission, or his employment with such contractor.

This report was prepared as an account of work
sponsored by the United States Government. Neither
the United States nor the United States Atomic Energy
Cominission, nor any of their employees, nor any of
their contractors, subcontractors, or their employees,
makes any warranty, express or implied, or assumes any
legal liability or responsibility for the accuracy, com-
pleteness or usefulness of any information, apparatus,
product or process disclosed, or represents that its use
would not infringe privately owned rights.

\section{PACIFIC NORTHWEST LABORATORY RICHLAND, WASHINGTON operated by}

BATTELLE MEMORIAL INSTITUTE

for the

UNITED STATES ATOMIC ENERGY COMMISSION UNDER CONTRACT AT(45-1)-1830 


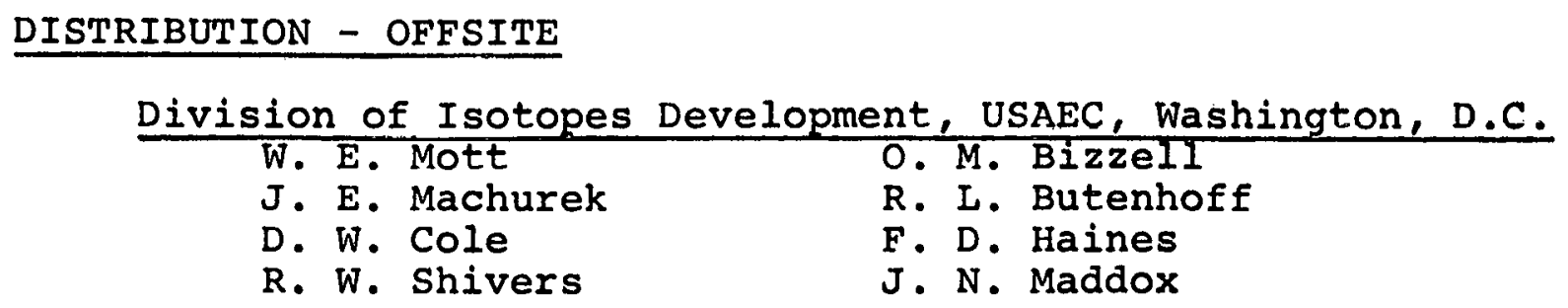

Division of Reactor Development \& Technology, USAEC, Washington, D.C. G. W. Cunningham

S. J. Seiken

M. Shaw

Division of Space Nuclear Systems, USAEC, Washington, D.C. R. T. Carpenter G. A. Newby

G. P. Dix J. A. Powers

M. Klein F. C. Schwenk

Mound Laboratory, Monsanto Corporation, Miamisburg, Ohio W. T. Cave

R. L. Neubert

Oak Ridge National Laboratory, Oak Ridge, Tennessee

P. S. Baker J. H. Gillette

A. F. Rupp

E. E。 Beauchamp

Oak Ridge Operations Office, USAEC, Oak Ridge, Tennessee D. C. Davis, Jr。

Richland Operations office, USAEC, Richland, Washington B. A. Ryan

Sandia Corporation, Albuquerque, New Mexico A. J. Clark, Jr, Department 9510

Savannah River Laboratory, Aiken, South Carolina D. H. Turno

Savannah River Operations Office, USAEC, Aiken, South Carolina W. D. Sandburg 


\section{DISTRIBUTION - ONSITE (BNW)}

J. L. Bates

R. E. Burns

T. D. Chikalla

F. T. Cross

G. J. Dau

D. R. de Halas

J. L. Deichman

D. E. Deonigi

K. Drumbeller

J. W. Finnigan

H. T. Fullam

V. I. Hammond

J. E. Hansen (2)

A. J. Haverfield

J. H. Jarrett

R. S. Kemper

R. W. McKee

$\mathrm{J}$. E . Minor

L. K. Mudge

D. R. Newman

R. E. Nightingale

R. W. Perkins

L. D. Perrigo

F. P. Roberts

C. A. Rohrmann

K. J. Schneider

K. I. Swinth

W. Vali

H. H. Van Tuyl

J. B. Vetrano

E. J. Wheelwright

N. A. Wogman

Technical Files (3) 


\section{PACIFIC NORTHWEST LABORATORY}

MONTHLY REPORT TO THE

DIVISION OF ISOTOPES DEVELOPMENT

FOR November 1970

08-01. RADIOISOTOPES PRODUCTION AND MATERIALS DEVELOPMENT

08-01-03. FISSION PRODUCTS

I. LOW COST CESIUM AND STRONTIUM SOURCES - H. H. Van TuYI and H. C. Stidham

The objective of this program is to provide technology for the production of inexpensive Cs and $S r$ sources by using the purified compounds generated in the Hanford Waste Management Program (HWMP). Large scale use of these radioisotopes wizl require an assessment of the capabilities of HWMP for producing suitable radiation and heat sources, acceptance of the HWMP product by the customer, licensing of the sources, and market development activities.

The goal in FY-Z972 is to develop equipment for fabricating smalier diameter sources in the HWMP facility. The incremental cost of producing smaller sources will be evaluated. Prototype sources will be fabricated with nonradioactive feeds, including loading capsules, welding, and NDT. The sources will be tested to determine mechanical integrity. Potential customers will be contacted to stimulate interest in the HWMP sources.

Temperature calculations were made for varying sizes of the doubly encapsulated strontium fluoride capsules. The density of the strontium fluoride product in these capsules was varied in increments of 58 from a low of $65 \%$ of theoretical density to a maximum of 908 theoretical density for each capsule size. All calculations were based upon a vertical cylinder 
orientation, suspended in $70^{\circ} \mathrm{F}$ air. The encapsulation material was Hastelloy $c$ metal. The heat generation rate was calculated at $95 \%$ of $\mathrm{Sr}^{90}$ theoretical values. This rate appears to closely approximate the actual waste management product.

The radius of the inner capsule was varied in 0.10 in. increments between a one and a two in. radus. A $15 \mathrm{mil}$ gap was left between the outside of the inner capsule and the inside of the outer capsule. A wall thickness of $120 \mathrm{mils}$ was used for each capsule.

A centerline temperature of $1463^{\circ} \mathrm{C}$ (the melting point of pure $\mathrm{SrF}_{2}$ ) is achieved with an putside diameter of 4 in. at 658 density, and 4.4 in. at 85 i density. Corresponding surface temperatures are $510^{\circ} \mathrm{C}$ and $595^{\circ} \mathrm{C}$, respectively. Smaller diameters will be necessary to avoid a molten core in actual material since impurities will reduce the melting point.

II. RADIATION CHARACTERISTICS OF FISSION PRODUCT Rh AND Pd F. P. Roberts

The traditional view of fission products is that they are waste materials, but some fission products, such as Rh, $P d, R u$, and Tc, have or will have future uses and should be considered for their resource potential. A resource strategy should be developed to determine the optimum technological and economic use of these elements. This study would answer these questions:

2. What is the market for $R h, P d, R u$, and $T c$ for the next 40 years?

2. What are the radiological hazards for the use of these elements on a benefit-risk basis?

3. Is there justification for a national policy requiring that these elements be set aside as a national resources stock-pile for future use?

4. What would be the impact of an almost irreversible storage of these elements on the economics of recovery if they are needed in the future? 
5. Is it economically desirable to perform a gross separation scheme that will separate these elements and store them for 20-50 years so that they will be available for future use?

\section{A. Rhodium and Palladium Research}

The scope of the rhodium and palladium study has been broadened to include the fission products technetium and ruthenium. The study which up to this time was limited to the evaluation of the radiation characteristic of fission product rhodium and palladium and methods for their recovery from wastes from fuels reprocessing will now encompass the marketability, safety aspects, economic feasibility, and a limited evaluation of the fabrication problems associated with the industrial application of these elements. The overall goal of this program is to determine if there is justification for the utilization of these four elements.

\section{B. $102 m_{\mathrm{Rh}}$ Half-Life}

Acquisition of data for the determination of the half-life of $102 \mathrm{~m}_{\mathrm{Rh}}$, which was resumed last month continues. The problems associated with the counting instruments have been resolved and good data are being obtained.

C. Recovery and Purification of ${ }^{144} \mathrm{Ce}$ (funded under Related Services)

The purification of ${ }^{144} \mathrm{Ce}$ and conversion to $\mathrm{CeO}_{2}$ has been finished and preparations are underway for encapsulation of the material for shipment to ORNL. 
Analysis of the cerium product shows a radiochemical purity greater than 99.98 for the $6200 \mathrm{Ci}$ that were recovered. Both the purity and quantity exceed the ORNL requirements.

III. EVALUATION OF LARGE SCALE USES FOR PURIFIED FISSION PRODUCT XENON - C. A. Rohrmann

of all the fission products, Xe has the highest fission yield. Although many of the Xe isotopes are radioactive, they all have such short half lives that their activity would be insignificant after allowing time for normal fuel reprocessing.

In the past, the extreme rarity of Xe in nature has clearly inhibited its consideration for specific large scale uses even where its properties give it definite and unique advantages. But now, Xe could be made available in supprisingly large quantities. Perhaps the most important and beneficial uses of Xe would be for human surgical anesthesia. Another of the potential uses is a filler gas in incandescent light bulbs with significant increase in both brightness and efficiency.

The scope of the PNL program is to: (I) establish the quality of $X e$ which an be accepted or generally licensed for consumer uses, (2) determine what industries would be interested in evaluating fission product Xe for large scale application, (3) distribute specimens to participating evaluators, (4) compile evaluation results, und (s) prepare a final roport on the results of this total effort.

The purification of the second and third volumes of xenon at Oak Ridge has been completed. In one case the residual ${ }^{85} \mathrm{Kr}$ activity was $4 \mu \mathrm{Ci}$, and in the other, less than $1 \mu \mathrm{Ci}$ per liter of xenon (STP). The chemical purity of the gas was better than 98\%. The shipment of the remaining available crude xenon was also made from NRTS to Oak Ridge. This material will be processed to complete the purification program for a total of about 1500 liters. 
Dose calculations applicable to fission product xenon use in human anesthesia show that for material containing $2 \mu \mathrm{Ci}$ of ${ }^{85} \mathrm{Kr}$ per liter administered over a four hour period of anesthesia, the dose amounts to $1.3 \mathrm{mrad}$. The average annual dose to the lungs of man from background radon irradiation is $200 \mathrm{mrad}$. The amount from a typical chest $x$-ray is about $40 \mathrm{mrad}$. Thus, the added dose from the use of fission product xenon can be regarded as insignificant or much less than the variations in dose rate that accrue to changes and differences in living patterns of and between individuals, such as changes in altitude, residing in masonry buildings instead of wood houses, occupation, etc.

Preliminary arrangements have been made to discuss an evaluation program with a prospective and interested user.

ISOTOPE PRODUCTION EVALUATIONS - R. W. MCKee, B. M. Cole, and R. G. Rau

This program is designed to evaluate major aspects of isotope production. Until recently, the principal source of isotopes has been the AEC production reactors. Now, however, power reactors are rapidly becoming important sources of isotopes. Power reactors also offer attractive prospects for target irradiations. The future availability and cost of these unique isotopes depend on full and efficient utilization of the production potential of power reactors, and the inherent value of these materials can have a significant impact on nuclear power costs.

The scope of this program includes analysis of fast and thermal reactor fuel cycles within the framework of an expanding nuclear power industry to identify the sources, quantities, timing and cost of production of isotopes of potential importance. 
A new task to develop an Isotope Data system was initiated in FY-2972. The objective is a computerized, quick-response system for answering queries on isotope properties, availability, applications, shielding requirements, decay compositions, toxicity, and other factors.

\section{A. Fission Product Profitability studies}

Activity for this task consisted primarily of preparing a series of draft illustrations that outline the bases and scope of the study, and a literature search for related studies.

A visit to BNL was made to obtain information and exchange views on procedures and bases for valuing fission-product cesium.

\section{B. Isotope Data Compilations}

Revision and updating of the nuclide data file has continued. After exploring possible approaches for handling internal conversion effects it was concluded that two separate gamma ray files would be developed to represent (a) decay scheme transitions

and (b) experimentally measured gamma photons. For the immediate objective of a "Nuclide Tables" revision, the experimental gamma data will be used. For the longer range objective of a data file for a versatile data system, the decay scheme transition data will be used as part of the data required for a more complete definition of internal conversion effects such as internal-conversion electron yields.

The revised data file, as it now stands, was used with ISOTAB II to produce a revised version of Table 2 of the "Nuclide Tables," and this table is now about $25 \%$ longer than the original version. With further additions and revisions yet to be incorporated, the length of this table may increase even further. 


\section{Isotope Data System}

Recent computer code debugging of the three-dimensional storage matrix in the information system has demonstrated this concept's feasibility。 Data stored in this third dimension is now being successfully retrieved; however, modifications to the logic in the report section of the program are necessary to allow proper display of the retrieved data. Because of the complexity of the program, the required revisions are being carried out one step at a time and the debugging is consequently a relatively slow process.

Visits were made to the Nuclear Data Center and Internal Dosimetry Center at ORNL and to the Cross section Center at BNL to obtain information on the scope of their activities and to determine if additional information useful to our isotope data file might be available. As a result of these visits, a computer program is being obtained from the Internal Dosimetry Center that may be adaptable to the data system for calculating internal conversion effects, and a revised compilation of resonance integrals has been obtained from the cross section center.

\section{8-01-04. SOURCE DEVELOPMENT}

I. NONDESTRUCTIVE TESTING OF SOURCES - D. R. Newman

A. NDT Research and Development Support

The scope of this program is to deverop methods of nondestructive examination of isotopic heat sources developed by DID contractoro. Through a number of programs, DID is developing applications for various radioisotopes as heat sources for specific applications. The PNL program wizl concentrate on the development of methods to assure the long-term mechanioal and thermal. integrity of the as-manufactured sources. 
Because it is important that NDT methods are compatible with capsule design, (e.g. welds should be physically accessible for inspection), the approach of this program is to become involved early with contractors who have design and development responsibilities. Continuing liaison will ensure that NDT methods are available for the sources under development.

A talk on the pulsed schlieren system, "Pulsed Laser Imaging system for Direct Visualization of Ultrasonic Waveforms" was given at the 80th meeting of the Acoustical society of America in Houston November 5th. A film taken with this system and showing ultrasonic wave propagation phenomenon was shown.

Fabrication difficulties prevented completion of the differential transducers this month; they will be finished in December.

The report on the multielement (more correctly a multielectrode) ultrasonic transducer system is ready for final typing. The title has been changed to more accurately reflect the contents and to allow better cross-referencing in information retrieval systems. The previous title was "Multielement Ultrasonic Transducer Test Techniques," and the new one is "Multielectrode Ultrasonic Transducer Test Techniques for Radioisotope Encapsulation Inspection". The report number, BNWL-1491, remains the same.

Sample development capsules for a typical heart power source were obtained for a brief study of the potential of nondestructively obtaining more information about the weld closure. 
II. TECHNOLOGY PUBLICATIONS - E. J. Wheelwright

The objective of this program is to provide technology for the use of $\mathrm{Pm}$ as a radioisotope heat source in aerospace or terrestrial applications. In the past, the program has included development of scientific and engineering data pertinent to:

(2) the purification of $\mathrm{Pm}$ and conversion to a useful fuel form, (2) the design and fabrication of $\mathrm{Pm}$ heat sources and (3) hazards analyses associated with radioisotopic heat sources. Presently, principal emphasis of the program is directed to the dissemination of $P m$ technology to the technical and scientific community.

The FY- 2972 goal is to complete arrangements for the publication of a book on Pm technology.

Fourteen of the fifteen chapters of the promethium book have been completed, and five copies of each completed chapter

have been sent to DID for review. Writing of the remaining chapter, Promethium Analytical Chemistry, Chapter 4, is nearly. completed and will be completed in December.

Copies of the completed chapters are currently under review by BNW management. The BNW and DID reviews are scheduled for completion on or before February 10, 1971.

III. ADVANCED SOURCE DEVELOPMENT - J. H. Jarrett

A. Advanced Alpha-Photon Source Development

The objective of this program is to evaluate present and future heat and radiatic source application requirements and to relate them to present and future encapsulation technology. 
The goal of the current work is concerned primarily with the development of thin-film encapsulation and evaluation techniques for alpha/photon sources. Emphasis will be directed toward the technique of sputtering as a means to obtain thin films of radioisotope and containment materials.

Effort in November was directed toward accomplishing preliminary tasks in support of the source preparation run scheduled for December. Critical components in the glovebox sputtering system were replaced, and the cold (nonradioisotopic) sputtering system was used to demonstrate the hardware that will be used in the December run. The cold system was also used to sputter deposit nickel on various substrate materials. Nickel is now under consideration as the sputterdeposited radioisotope containment window material for sources to be prepared in the near future.

The glovebox sputtering system is now in good operating condition. Critical o-ring seals and the seals on the rotating shaft for the " $J$ " substrate station were replaced. These measures promise a better initial vacuum and reduce the air leak rate into the system. The result should be higher quality sputtered deposits. While the glovebox system was partially disassembled to replace the seals, a second sputtering target station was installed. Electrical connections will be made at a later date. This addition will allow sequential sputtering of two different materials without exposing the substrate material to air.

The hardware that will be used in the December source preparation run was evaluated, using the cold sputtering system, and found to be satisfactory. 
Sputtered 304 stainless steel has been used as a containment window for previously prepared sources; however, this material has demonstrated an apparent tendency to rust in discrete locations when exposed to either boiling water or hot, high humidity air for extended periods of time. For this reason, other materials are being considered for use as the final radiation source window material. Nickel has been selected as a candidate for consideration. Experiments on the sputtering characteristics of nickel were started. Preliminary results indicate that it forms a good quality film on glass and stainless steel substrates and a poorly adhering film on copper substrates. The poor adherence of sputtered nickel on copper may be due to a thin black layer (probably CuO) that forms on the copper substrate if it is sputter cleaned for more than a few minutes. This situation should be improved by sputter cleaning the copper for a reduced time period, by minimizing the residual air and the air leak rate into the system, and by keeping the copper substrate at a lower temperature through better thermal contact with the water-cooled substrate base plate. The ability of the subject materials to adhere to copper is quite important in this work since the radioactive layer of the sources to be prepared in the near future will be a sputter-deposited mixture of $24 \mathrm{IAmO}_{2}$ and copper.

$$
\text { 08-02. THERMAL APPLICATIONS }
$$

08-02-01. CIRCULATORY SUPPORT SYSTEMS - F. T. CrosS \& J.C. Sheppard

A. Radiation Characteristics - Nonpromethium Systems

The objective of this program is to determine the dose from radioisotopic heat sources suitable for circulatory support systems. This is accomplished by measuring the dose rates within and surrounding various tissue equivalent phantoms. 
Part of the program concerns the prediction of the measured dose rates by the development

of computational codes. The computer codes are also used in parametric studies and for the prediction of the in-phantom dose rates from sources not available for measurement.

LASL-1 was placed in the homogeneous phantom for repeat measurements of the photon dose rates. These measurements will be compared with the earlier values to determine the influence of the ${ }^{236} \mathrm{Pu}$ daughter impurities.

The Rankine dosimetry model was received from Hittman Associates, Inc., and is being readied for the in-phantom measurements which will commence when the heat source is supplied by LASL.

${ }^{238} \mathrm{Pu}$ source continue.

Computations of organ dose rates from an implanted $30-W$

$$
\text { 08-03. RADIOISOTOPE SYSTEMS DEVELOPMENT }
$$

08-03-03. OCEANOGRAPHIC AND NATURAL RESOURCE APPLICATIONS

I. MARINE SYSTEMS

A. Nuclear Technigues for Seabed Mineral Exploration R. W. Perkins and N. A. Wogman

Recent PNL studies of the composition of deep ocean sediments demonstrated that various mineral deposits and commercial-grade ores can readily be identified by neutron activation and instrument analysis. From preliminary analysis, it is evident that the elemental composition of most mineral deposits can be easily identified 


\begin{abstract}
at concentrations well below those of economic importance. Actual experience with Cf-252 as a neutron source has confirmed these conclusions. Two methods for in-place seabed mineral exploration are being investigated: the first involves placing a neutron source and detector system on the ocean floor; the second method involves bringing samples on board ship and employs a shipboard $C f-252$ irradiator and a $G e(L i)$ spectrometer. The former has the advantage of very rapid analyses, and the latter provides definition of mineral depth profiles from core samples.
\end{abstract}

The major effort during the past month has been to determine the sensitivity with which the various elements can be measured in a simulated ocean floor matrix. Known amounts of the various elements of interest were homogeneously mixed in a dunite matrix, then irradiated and counted in geometries which simulate those which will exist in actual ocean floor analysis. These calibrations will provide a basis on which the sensitivity for the measurement of any element of interest in any elemental matrix can be determined. The calibrations and sensitivity calculations are based on both 2 and 10 minute irradiation and counting periods to establish what the maximum sensitivity is for practical analytical time periods.

Since the actual sea floor areas are not necessarily flat, the bias caused by various degrees of uneveness in an irradiated surface are being investigated. The nuclear probe design has been modified somewhat to insure a minimum bias where an uneven sea floor surface is encountered and to eliminate the possibility of the instrument jamming when the positions of the irradiator and the detector are reversed. 
PROMETHIUM INVENTORY - November 30,1970

Received from ARHCO

Transfers and Shipments

Concentrated Feed

Product

Run 22, $435 \mathrm{ci} / \mathrm{gm}$

Run $40,500 \mathrm{ci} / \mathrm{gm}$

Run 55, $646 \mathrm{Ci} / \mathrm{gm}$

Run 57, $908 \mathrm{ci} / \mathrm{gm}$

Waste

Unaccounted

Decay

Total
$16,361,900 \mathrm{Ci}$

$1,498,520$

$5,051,285$

18,585

33,960

76,435

72,375

634,115

$1,276,650$

$7,699,975$

$16,361,900$

Production and Transfers

None 
DID BUDGET STATUS - FY-1971 Through November 29, 1970

Cost $\begin{gathered}\text { Cost to } \\ \text { Date }\end{gathered}$ Budget

08-01 Radioisotope Production and Materials Development

08-01-03 Fission Products

I. Low-Cost Cs/Sr Sources

$9.5 \quad 30.0$

80

II. Rhodium, Palladium, Ruthenium, and Technetium

0.9

11.1

III. Xenon

0.7

1.7

20

IV. Evaluation of Isotopes Production

Subtotal 08-01-03

$\frac{12.8}{23.9}$

$\frac{59.5}{102.3}$

$\frac{80}{200}$

08-01-04 Source Development

I. NDT R\&D Support

3.8

12.3

II. Technology Publications

3.3

19.3

20

III. Advanced Source Development

$\therefore \quad$ Subtotal 08-01-04

$\frac{4.4}{1+5}$

$\frac{37.4}{69.0}$

$\frac{50}{95}$

Subtotal $08=01$

35.4

171.3

295

08-02 Thermal Applications Development

08-02-01 Circulatory support systems
I. Circulatory Support
$\frac{11.4}{11.4}$
$\frac{43.8}{43.8}$
$\frac{85}{85}$ 


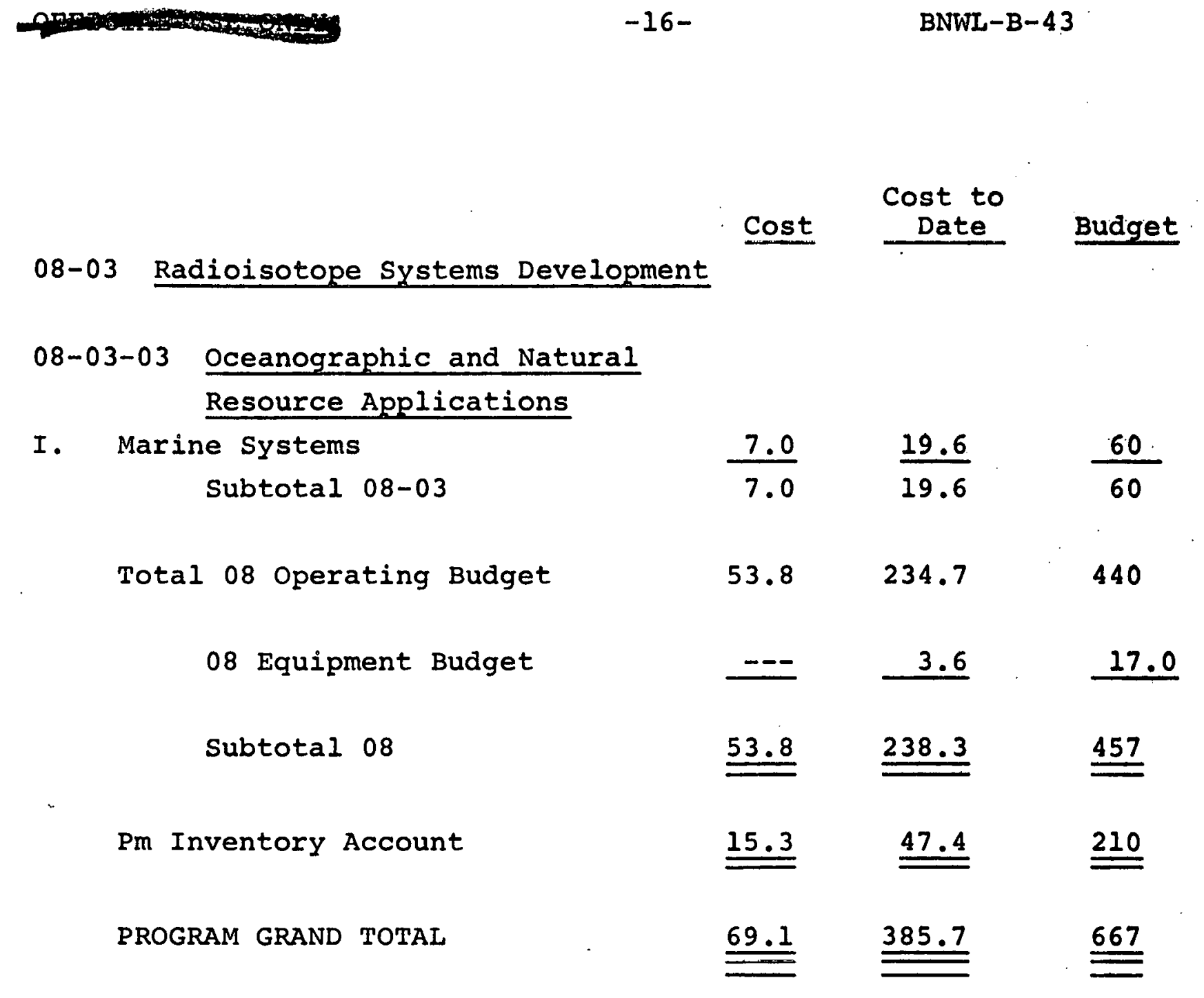

